\title{
Süleyman Demirel Üniversitesi Öğretim Elemanları ve Öğrencilerinin Yerleşke İçindeki Rekreasyonel Talep ve Eğilimleri
}

\author{
Atila GÜL*, Emine KELEŞ, Ömer Faruk UZUN \\ Süleyman Demirel Üniversitesi, Mimarlık Fakültesi Peyzaj Mimarlığı Bölümü, 32260, Isparta, Türkiye \\ *e-mail: atilagul@sdu.edu.tr \\ Öz \\ Günümüzde üniversite yerleşkeleri, eğitim-öğretim ve bilimsel çalışmalarının yürütülmesi yanı sıra rekreasyonel, \\ sosyal, ekolojik ve ekonomik açııından çok yönlü işlevleri ile önemli yaşam mekanlarıdır. Bu çalışmada, \\ Süleyman Demirel Üniversitesi (SDU) öğretim elemanları ve öğrencilerinin Yerleşke içinde rekreasyonel eğilimleri \\ ve taleplerinin belirlenmesi amaçlanmıştır. Çalışmada SDU 15 Fakültede görev yapan 150 akademisyen ve \\ toplam 375 ögrrenciye tesadüfi olarak anket yöntemi ile veriler elde edilmiş ve veriler sayısal yüzdeleri ve \\ istatistiki olarak birbirleriyle ilişkisi ortaya konulmuştur. Sonuçta, SDU Yerleşkesinin rekreasyonel açısından \\ önemli bir potansiyele sahip olduğu, genelde hafta içinde ortalama 3 veya 4 gün rekreasyonel faaliyetlere \\ katılımın gerçekleştiği belirlenmiştir. Yerleşke içinde yüksek oranda taleplerin olmasına rağmen rekreasyonel \\ mekânların ve etkinliklerin nitelik ve nicelik açısından yetersiz olduğu ve yönetim organizasyonu açısından \\ istenilen düzeyde olmadığı ortaya çıkmıştır. SDU Yerleşkesinde en çok talep edilenler; Çok amaçlı çarşı \\ konseptinde mekanlar, kafe ve restoran, oyun alanları, konser, oditoryum vb. sosyal ve kültürel mekanlar, dış \\ mekan oturma ve dinlenme alanları, koşu ve bisiklet yolları vb. olarak belirlenmiştir.
}

Anahtar Kelimeler: Rekreasyon, Serbest zaman, Süleyman Demirel Üniversitesi, Öğretim elemanları, Öğrenciler, Yerleşke

\section{Recreational Demand and Trends in the Campus Students and Lecturers of Süleyman Demirel University}

\begin{abstract}
Nowadays, the university campuses are very important living areas with multiple functions including conducting educational and scientific works as well as recreational, social, ecological and economic functions. This study was aimed to determine the recreational trends and demands of the lecturers and students in the campus of the Suleyman Demirel University (SDU). In the study, data was obtained from 150 academics and 375 students in 15 faculties of SDU campus by randomly survey method. However, data was revealed the relationship with quantitative and statistical. Finally, SDU Campus has significant potential in terms of recreational value and recreational activities is estimated to occur on average 3 or 4 days usually in the week. Despite high demands on campus, and is insufficient in terms of quantity and quality of recreational spaces and activities of the organization in terms of Directors that is not on the desired level has emerged. the most demands were the multi-purpose market places, cafe and restaurants, playgrounds, concert, auditorium, social and cultural spaces, outdoor recreation areas, jogging and cycling paths and etc. in the Campus of SDU.
\end{abstract}

Keywords: Recreation, leisure, Suleyman Demirel University, Lecturers, students, campus

\section{Giriş}

Modern toplumlarda, sosyal, ekonomik, kültürel, teknolojik ve siyasal gelişmelere paralel olarak, rekreasyon ve serbest/boş zaman kavramları önem kazanmakta ve insan yaşamında önemli bir rol üstlenmektedir. Serbest zaman kişilerin bulundukları sosyal yapı içerisinde yaşamlarını sürdürebilmek ve daha yüksek bir düzeye ulaştırabilmek için zorunlu olarak yaptıkları çaba ve eylemler dışında kendi isteklerine göre değerlendirmede serbest oldukları süre olarak tanımlanabilir. İngilizce "leisure" (serbest zaman) Latince izinli veya özgür, serbest anlamına gelen "licere" kelimesinden türemiştir. 
Brightbill (1960) serbest zamanı, yaşam için gerekli olan, fizyolojik ve biyolojik ihtiyaçlar ve hayatın devamı için yaşamsal önemi olan faaliyetleri gerçekleştirdiğimiz zaman dışında kalan, tamamen isteğe bağlı yani kişinin kendi tasavvuru ve seçimine göre kullandığı zaman olarak tanımlamıştır (i̇skender vd., 2015). Serbest zamanın iki koruyucu özelliğinden bahsedilmektedir. İlki sosyal destek sağlaması, ikincisi kendi hür iradesini ortaya koyabilme inancı (self determinasyon) üzerindeki artırıcı etkisidir (Iwasaki and Mannell,2000; Iwasaki and Schneider, 2003). "Boş zaman" basit anlamıyla dolu olmayan zaman dilimidir bu kavram çoğu kez serbest zaman ile karıştırılabilse de kişinin çalışma dışı faaliyetler için kullandığı zaman aralığı olup, serbest zamanın bir parçasıdır (Demir ve Demir, 2007). Rekreasyon ise kişilerin serbest zamanları içerisinde, günlük yaşamın sıkıcı, disiplinli ve monoton geçen çalışmasının etkisinden kurtulmak, dinlenmek ve hoşça vakit geçirmek amacıyla bireyin kendi isteği ve iç itimi sonucu oluşan, bireyi fiziksel ve düşünsel yönden yenilemeyi amaçlayan; bireyin toplumsal, ekonomik, kültürel olanakları ve yaşadığı toplumun yapısı ile bağımlı olarak yapılan fiziksel etkinlikler bütünü olarak tanımlanmıştır (Koç, 1991; Uzun ve Altunkasa, 1991). Rekreasyon, insanın öz benliğine uygun ve yapmaktan zevk aldığı toplumsal, kültürel ve sportif etkinliklere katılarak, günlük yaşamın sıkıcılığından kurtulması ve başka insanlarla etkileşerek toplumsal bir kişilik kazanması olarak açıklanır (Bucher and Bucher, 1974). Rekreasyona duyulan ihtiyaç, rekreasyon faaliyetlerinin kişisel ve toplumsal olarak sağladığı faydalardan ileri gelmektedir. Kişisel yönden; fiziki sağlık gelişiminin yaratılması, ruh sağlığı kazandırılması, insanı sosyalleştirmesi, yaratııılık, kişisel beceri ve yeteneğini geliştirmesi, çalışma başarısı ve iş verimine etkisi, ekonomik hareketlilik, insan mutlu etmesi, toplumsal yönden ise; toplumsal dayanışma ve bütünleşmeyi sağlaması ve demokratik toplum yaratılması, rekreasyona duyulan ihtiyacın nedenlerinden bazılarını oluşturmaktadır (Karaküçük, 2008).

Teknolojik gelişmelerle insanların serbest zamanlarının artışı, eğitim ve gelir düzeylerinin yükselmesi ile yaşam sürelerinin uzaması gibi etkenler sonucu rekreasyonel etkinliklere olan talep artmıştır (Mansuroğlu, 2002). Dolayısıyla da günümüzde rekreasyon; fiziksel, sosyal, kültürel ve ekonomik yönleri olan kişilerin ve ulusların yaşam biçimini etkileyen önemli bir unsur haline gelmiştir. Bu faktörler, rekreasyona katılım açısından da çok önemlidir. Tezcan (1982)'ye göre rekreasyona duyulan intiyaç, rekreasyon etkinliklerinin kişisel ve toplumsal olarak sağladığı yararlardan ileri gelmektedir. Bu yararlar şöyle gruplandırılabilir (Kiper, 2009);

- Kişisel yararlar; bedensel, ruhsal, sosyal, psikolojik ve yaratıcılık bakımından aktiflik sağlar, ruhsal ve fiziksel sağılı gelişimi yaratır, bireye kendini ifade etme imkânı verir, yeni bilgi, beceri ve deneyimler kazandırır, yaratıcı gücü geliştirir, bireyi sosyalleştirir, bedensel ve ruhsal dinlenmeyi sağlar, çalışma başarısı ve iş verimini arttırır.

- Toplumsal yararlar; toplumsal dayanışma ve bütünlüğü sağlar, demokratik toplumun gelişmesini sağlar.

Rekreasyon etkinlik alanları; boş zamanın şekline, süresine, katılımın tarzına, iklim, ekonomik, coğrafi durum ile toplumun kültürüne göre farklılıklar ya da çeşitlilikler gösterebilmektedir. Ayrıca rekreasyon faaliyetleri, sosyal konumlara paralel olarak değişik ihtiyaç düzeyleri de gösterebilmektedir. Pehlivanoğlu (1986)'na göre, rekreasyonel etkinliklerin sürdürüldüğü mekanın özelliklerine göre, "kapalı" ve "açık hava" rekreasyonundan ibaret olup kapalı yer rekreasyonu, konutlar başta olmak üzere, geliştirilmiş çeşitli iç mekanlarda sürdürülen rekreasyon çeşidini kapsamakta ve özellikle bireylerin günlük yaşamlarındaki ağırlık ve yaygınlığıyla karakterize edilmektedir. Açık hava rekreasyonu ise, doğal koşullara dönük olarak bireylere daha geniş mobilite olanakları sunan ve açık havada peyzaj mekanlarında gerçekleştirilen rekreasyon çeşidinden oluşmaktadır.

Bireylerin kişilik özellikleri ve meslek seçimlerinin yanında, sosyal konumu rekreasyon faaliyeti seçimini etkileyen önemli bir faktördür. Yapılan araştırmalar, rekreasyon faaliyetlerinin seçiminin, bireylerin kişilik özellikleriyle ve seçtikleri mesleklere de paralellik gösterdiğini ortaya koymuştur (Tunçkol ve Çumralıgil, 2005). Eğitim ve rekreasyon bir bütün olarak ele alındığında rekreasyon 
eğitimin bir parçası olup, eğitim aracı olarak kullanılabilmektedir. Bu araç verimliliğin anahtarı olduğu gibi ayrıca kişinin fiziksel, toplumsal ve psikolojik gelişimi için de bir taban oluşturmaktadır (Dawer and Pangraz, 1975).

Kampus sözcügü ilk olarak A.B.D' de 18. yüzyılın ikinci yarısında Princeton'da kullanılmış olup kolej veya üniversite binaları arasındaki açıklıklar olarak tanımlanmıştır. Günümüzde ise "Kampus" kelimesinin eş anlamlısı olarak kullanılan "Yerleşke" kelimesi üniversitenin sınırları içindeki tüm kapalı mekânlar ile açık ve yeşil alanları kapsayacak şekilde tanımlanmaktadır (Arkun ve Özkal 2005). Günümüzde üniversite yerleşkeleri, eğitim-öğretim ve bilimsel çalışmalarının yürütülmesi yanı sıra rekreasyonel, sosyal, ekolojik ve ekonomik çok yönlü işlevleri ile önemli yaşam mekanları konumundadır. Bununla birlikte kentlerinde en önemli açık yeşil alanlarıdır. Bu bağlamda Üniversite yerleşkeleri, hizmet edenler (Akademik ve idari personel) ve hizmet alanlar (öğrenciler, veliler, kent insanları ) için sosyal, kültürel, fiziksel, zihinsel ve düşünsel gelişmenin sağlaması açısından önemli rekreasyonel alanlardır. Genel bir yaklaşımla rekreasyon, özellikle üniversite personeli ve öğrencileri için akademik eğitimin bir parçası ve yaşamsal ihtiyaç olarak kabul görmektedir. Ülkemizde 2547 Sayılı Yüksek Öğretim Kanunu'nun 47. maddesi “Yüksek Öğretim Kurumları'nın yapacağı plan ve programlar uyarınca öğrencilerin beden ve ruh sağlı̆̆ını korumak, beslenme, çalışma, dinlenme, boş zamanları değerlendirme gibi sosyal intiyaçlarını karşılamak ve mekânlar oluşturmak ve en iyi şekilde yararlanmaları için gerekli önlemlerin alınmasını içermektedir. Bir üniversite yerleşkesi kendi kendine yeter bir yapıya sahip olabilmesi için eğitim-öğretim yapılarının dışında, sağlık, merkezi yönetim yapıları, sosyokültürel faaliyetler merkezi ve alanları, kütüphane, kapalı spor merkezi ve alanları, araştırma geliştirme merkezleri, konaklama, alışveriş merkezleri, destek birimleri ve dış mekân kullanım alanları gibi işlevselliklere sahip olmalıdır.

Bu nedenle Üniversite Yerleşkesinin bütüncül mekânsal planlarının yapılması ve kapalı ve peyzaj mekanları ile hizmet veren ve hizmet alanların her türlü sosyal ve kültürel ihtiyaçların karşılanması da zorunlu olarak karşımıza çıkmaktadır. Üniversite öğrenimi, öğrencilerin davranış biçimlerini şekillendiren en önemli süreçtir. Bu kapsamda öğrenciler rekreasyon kavramının kendi hayatlarındaki öneminin bilincinde olmak suretiyle öğrenme, keşfetme, inceleme, araştırma merakı, sosyal iletişim, yararlı alışkanlık kazandırma ve stres azaltma anlamında bir fırsat yaratabilmektedir. Buna göre, rekreasyon verimliliğin anahtarı olduğu gibi ayrıca kişinin fiziksel, toplumsal ve psikolojik gelişimi için de bir taban oluşturabilmektedir (Dawer and Pangraz 1975; Özbaydar 1983; Wells and Merriman 2002; Tekin vd., 2007; Kiper, 2009). Görüldüğü üzere yerleşkelerin biçimlenişi ve gelişimini etkileyen birçok değişik faktör vardır. Üniversitenin kendine özgü eğitim politikası, yerleşkenin konumu ve özellikleri, tasarımcıların yaklaşımları ve kullanıcıların beklentileri de planlamalarda önem taşıyan diğer önemli hususlardandır (Kiper, 2009).

Bu çalışmanın amacı; Süleyman Demirel Üniversitesi Yerleşkesinde öğretim elemanları ve öğrencilerinin yerleşke içinde rekreasyonel faaliyetlere karşı talep, eğilim ve beklentilerin belirlenmesidir. Elde edilen bulgular doğrultusunda, SDÜ yerleşkesinin mekânsal planlama\& tasarımı ve yönetimine yönelik karar vericilere rehber niteliğinde katkı sağlaması amaçlanmıştır.

\section{Materyal ve Yöntem}

Süleyman Demirel Üniversitesi, 1992 yılında Isparta'da kurulmuş ve bünyesinde 19 Fakülte, 3 Yüksekokul, ön lisans eğitim veren 20 Meslek Yüksekokulu, lisansüstü eğitim veren 6 Enstitüsü ile 46 Araştırma Uygulama Merkezinden oluşmaktadır. 2016 yılı itibari ile SDU mevcut toplam öğrenci sayısı 86.058 olup (Lisans:38.042, Ön lisans:35.721, Yüksek Lisans:11.014; Doktora:1508), SDU Doğu ve Batı Yerleşkelerinden yararlanan yaklaşık 65 binin üzerinde öğrenci olduğu tahmin edilmektedir. 2015 yılı itibari ile öğretim elemanı sayısı 2160, idari personel sayısı ise 1342 dir. SDU Doğu ve Batı Yerleşkelerinin toplam alanı 643,179 ha'dır. Bu alanın 258,552 ha'ı eğitim amaçlı bina ve tesisler, 23,352 ha'i sosyal amaçlı bina ve tesisler, 149,275 ha'ı spor amaçlı bina ve kapalı tesisler, 183,900 ha'ı açık ve yeşil alanlar, 28,100 ha'ı ise Süleyman Demirel Botanik Bahçesi alanları oluşturmaktadır. SDU Yerleşkesinde kültür merkezleri, sanat evleri, yemek salonları, kafeteryaları, spor üniteleri, banka, iletişim ve ulaştırma ofisleri, yurtları, eğlence mekânları, öğrenci meydanı ve şenlikleriyle gündüz ve 
gece canlı bir yaşam alanıdır. Yerleşke içinde 80 'e yakın öğrenci kulübü bulunmaktadır. Çok amaçlı Atatürk Kapalı Spor Salonu (basketbol, voleybol, fitness, step, aerobik, tırmanma duvarı ve masa tenisi vb), olimpik yüzme havuzu ve açık alanda çim saha futbol, basketbol, hentbol, voleybol, amfi tiyatro, halı saha, 1 adet futbol sahası, tenis kortları, atletizm pisti vb. alanlar mevcuttur.

Üniversite Spor Bilimleri alanındaki altyapı ve imkânları nedeniyle Isparta, ulusal ve uluslararası sporcuların tercih ettiği yerlerden birisi konumundadır.



Şekil 1. SDÜ Yerleşkesinin mevcut durumu

Yöntem olarak SDÜ Doğu ve Batı Yerleşkesinde bulunan Lisans eğitim ve öğretim faaliyeti sürdüren 15 Fakültede 2012-2013 yıllarında anket çalışması yapılmıştır. Yerleşke içindeki 15 Fakülte (Fen Edebiyat F. İlahiyat F. Orman F. Ziraat F. İktisadi ve İdari Bilimler F. Sağlık Bilimler F. Teknik Eğitim F., Teknoloji, F., Mühendislik F., Güzel Sanatlar F., Mimarlık F. Hukuk F., Eğitim F., Tıp F., Diş Hekimliği F.) için homojen sayı belirlenmiş ve her Fakülteden 10 akademisyen olmak üzere toplam 150, her Fakülteden ise 25 öğrenci olmak üzere toplam 375 öğrenciye rastgele anket çalışması öngörülmüştür. 2013-2014 öğretim yılında SDÜ'de görev yapan 1500 öğretim elamanların \% 10'nu oluşturmaktadır. Çalışma amacı doğrultusunda uygulanan anketi dolduracak akademik personel, bölüm ağırlıklarına ve unvanlarına bakılmaksızın tesadüfi yöntemle seçilmiştir. Çalışma; kapsam ve yöntemin belirlenmesi, konuya ilişkin bilgilerin toplanması, anket sorularının hazırlanması, anketin uygulanması ve verilerin değerlendirilmesi şekilde tamamlanmıştır.

Ankete katılan öğretim elemanları ve öğrencilere 23 soruluk bir anket formu uygulanmıştır. Veriler SPSS Statistics 20 programında değerlendirilmiştir. Öğretim elemanları ile öğrencilerin yüzde ve ortalama değerleri belirlenmiş ve arasında Pearson Chi-Square testleri uygulanarak $p=<0.01$ açısından anlamlı ilişki olup olmadığı araştırılmıştır. Anket formunda yer alan sorularla akademisyen 
ve öğrencilerin demografik bilgileri (genel profili), serbest zaman ve rekreasyon faaliyetlerine yönelik kavramsal yaklaşımları, rekreasyonel faaliyetlere eğilimleri, talepler ve yorumlar kapsamında değerlendirilmeye çalışıımıştır.

\section{Bulgular ve Tartışma}

\subsection{Genel Profil}

Ankete 150 öğretim elemanı ve 375 öğrenci katılmıştır. Ankete katılan öğretim elemanlarının \% 43'ü bayan, \% 56,7'si erkek, öğrencilerin ise \% 48,8'u bayan \% 51,2'i ise baydır. Denek grupları içinde öğretim elemanlarının \% 24'ü, öğrencilerin ise \%61'si 20-30 yaş aralığında, öğretim elemanlarının \% 24 'ü ve öğrencilerin \% 38'i ise 31-40 yaş aralığında yer almaktadır. Ankete katılan öğretim elemanlarının \% 26'sı Yrd. Doç. Dr., \% 22'si Prof. Dr., \% 13'ü Doç. Dr., \% 13'ü Öğretim Görevlisi, \% 7,3'ü Dr., \% 4'ü Uzman, \% 3'ü Okutman, \% 1'i ise araştırma görevlisi olarak görev yapmaktadır. Öğrencilerin ise \% 100'ü Lisans öğrencilerinden seçilmiştir (Çizelge 1).

Kalınan ikametgâh yerleri açısından öğretim elemanlarının \% 88,7'si Isparta Merkezde, \% 11,3'ü ise diğer kent merkezi dışında veya diğer şehirlerde, öğrencilerin ise \% 95,2'si Isparta kent merkezinde, \% $4,8^{\prime} i$ ise diğer şehirlerde ikame etmektedir. Öğretim elemanlarının \% 60'ı kendi evinde kalmakta, \% 2,7'si apartta, \% 3,3'ü ailesiyle, \% 34'ü ise kirada olduğu ifade edilmiştir. Öğrencilerin ise \% 29,3'ü KYK, \% 20,5'i Özel yurtta, \% 22,9'u apartta, \% 18,7'si evde, \% 5,6'sı ise ailesiyle beraber yaşamaktadır (Çizelge 1). Yerlisu Lapa ve Ardahan( 2009) yaptığı çalışmada, Akdeniz Üniversitesindeki öğrencilerin \% 39,2'si kiralık evde, \% 30,1'l ise aile yanında kaldığını ifade etmiştir.

Çizelge 1. Ankete katılanların genel profili

\begin{tabular}{|c|c|c|c|c|}
\hline \multicolumn{2}{|c|}{ Genel Profil } & \multirow{2}{*}{$\begin{array}{c}\text { Öğretim Elemanları (\%) } \\
43,3\end{array}$} & \multirow{2}{*}{$\begin{array}{c}\text { Öğrenciler (\%) } \\
48,8\end{array}$} & \multirow{2}{*}{$\begin{array}{c}\text { Toplam (\%) } \\
47,2\end{array}$} \\
\hline & Bayan & & & \\
\hline minger & Erkek & 56,7 & 51,2 & 52,8 \\
\hline \multirow{4}{*}{ Yaş } & $20-30$ yas & 24,0 & 61,6 & 50,9 \\
\hline & $31-40$ yas & 27,3 & 37,6 & 34,7 \\
\hline & $41-50$ yas & 24,7 & 0,8 & 7,6 \\
\hline & $51-60$ yas & 24,0 & 0,0 & 6,9 \\
\hline \multirow{9}{*}{ Konum } & Prof. Dr. & 22,0 & & \\
\hline & Doç. Dr. & 13,3 & & \\
\hline & Yrd. Doç. Dr. & 26,0 & & \\
\hline & Dr. & 7,3 & & \\
\hline & Öğretim Görevlisi & 12,7 & & \\
\hline & Okutman & 3,3 & & \\
\hline & Uzman & 4,0 & & \\
\hline & Araştırma Görevlisi & 11,3 & & \\
\hline & Lisans Öğrencisi & 0,0 & 100,0 & \\
\hline \multirow{2}{*}{ İkametgâh } & Isparta & 88,7 & 95,2 & 93,3 \\
\hline & Diğer & 11,3 & 4,8 & 6,7 \\
\hline \multirow{5}{*}{ Kalınan Yer } & KYK & 0,0 & 29,3 & 14,7 \\
\hline & Özel Yurt & 0,0 & 20,5 & 10,3 \\
\hline & Apart & 2,7 & 22,9 & 12,8 \\
\hline & Kendi Evim & 60 & 18,7 & 39,3 \\
\hline & Ailem & 3,3 & 5,6 & 4,5 \\
\hline
\end{tabular}




\subsection{Kavramsal Yaklaşım}

Ankete katılanların yerleşke konseptine uygun yeşil alan, serbest zaman, rekreasyon gibi kavramlar ve faaliyetleri hakkındaki yaklaşımları veya yorumları belirlenmiştir. Elde edilen bulgular kapsamında; Öğretim elemanları ile öğrenciler arasında kavramsal yaklaşımlar açııından istatistiki açıdan önemli farklılıklar vardır.

Yeşil alan kavramı konusunda; öğretim elemanlarının \% 36,7'si dinlendirici ve huzur verici \% 25'i temiz hava, \% 16,7 si ise bitki örtüsü ile kaplı açık alanlar şeklinde yorumlarken öğrencilerin \% 48,8'i ormanlık alan, \% 14,9'u dinlendirici ve huzur verici, \% 13,6'sı ise çimenlik ve çayırlık alan olarak algıladıkları belirlenmiştir (Çizelge 2). Öğretim elemanları ile öğrenciler arasında yeşil alan kavramı konusunda algısal olarak farklı değerlendirdikleri ve bilgilenme konusunda eksikliklerin olduğu anlaşıımaktadır.

Çizelge 2. Yeşil alan kavramı

\begin{tabular}{|c|c|c|c|c|}
\hline & & Öğretim Elemanları (\%) & Öğrenciler (\%) & Toplam (\%) \\
\hline \multirow{14}{*}{$\begin{array}{l}\text { Yeşil alan } \\
\text { kavramının } \\
\text { anlamı }\end{array}$} & Dinlendirici ve Huzur Verici & 36,7 & 14,9 & 25.89 \\
\hline & Ormanlık Alan & 0,7 & 48,8 & 24.84 \\
\hline & Temiz Hava & 25,3 & 2,7 & 14.05 \\
\hline & Bitki Örtüsü ile Kaplı Acık Alanlar & 16,7 & 7,2 & 11.99 \\
\hline & Çimenlik ve Çayırlık & 0 & 13,6 & 6.82 \\
\hline & Doğa ve Çevre Gezileri & 7,3 & 0,0 & 3.66 \\
\hline & Piknik Alanları & 0,7 & 5,9 & 3.31 \\
\hline & Doğa Yürüyüşleri & 5,3 & 0,0 & 2.66 \\
\hline & Sadece Park Alanları & 3,3 & 1,1 & 2.21 \\
\hline & Doğayla Bütünleşme & 0,7 & 2,9 & 1.81 \\
\hline & Estetik & 2,0 & 0,8 & 1.40 \\
\hline & Çalılık & 1,3 & 0 & 0.65 \\
\hline & Yaşamı Anlama & 0,0 & 1,1 & 0.55 \\
\hline & Uyumluluk & 0,0 & 0,3 & 0.15 \\
\hline
\end{tabular}

Pearson Chi-Square Value $260,647^{\text {a }}$ df:15, ${ }^{*} \mathrm{p} \leq 0.0001$

Serbest zaman kavramı konusunda; Öğretim elemanlarının \% 33'ü boş vakit, \% 30,7'si işten sonra arta kalan zaman, \% 17,3'ü ise eğlenme, dinlenme ve istenilen aktivitelerin gerçekleştiği zamanlar olarak belirtirken öğrenciler ise; \% 36'sı zorunlu yaşam koşulları dışında kalan zaman, \% 22,4'ü boş vakit, \% $18,9 \mathrm{u}$ ise isteğe göre şekillenen zaman, \% 15,2'si ise işten sonra arta kalan zaman olarak algılamışlardır (Çizelge.3). Serbest zaman kavramı açısından ise, kavramın tam olarak bilinmediği ve boş zaman ile eş değer tutulduğu anlaşılmaktadır.

Çizelge 3. Serbest zaman kavramı

\begin{tabular}{|c|c|c|c|c|}
\hline & & Öğretim Elemanları (\%) & Öğrenciler (\%) & Toplam (\%) \\
\hline \multirow{4}{*}{$\begin{array}{l}\text { Serbest zaman } \\
\text { Kavramının } \\
\text { anlamı }\end{array}$} & Boş vakit & 33,3 & 22,4 & 28.6 \\
\hline & İşten sonra arta kalan zaman & 30,7 & 15,2 & 23.5 \\
\hline & $\begin{array}{c}\text { Zorunlu yasam koşulları dışında kalan } \\
\text { zaman }\end{array}$ & 5.3 & 36,0 & 18.6 \\
\hline & İsteğe göre şekillenen zaman dilimi & 4,0 & 18,9 & 11.7 \\
\hline
\end{tabular}




\begin{tabular}{cccc}
\hline $\begin{array}{c}\text { Eğlenme dinlenme ve istenilen } \\
\text { aktivitelerin gerçekleştiği zamanlar }\end{array}$ & 17,3 & 4,8 & 11.3 \\
\hline Seçme şansının insana ait olduğu zaman & 6,0 & 2,7 & 4.5 \\
\hline Rutin isler dışında kalan zaman & 2,7 & 0,0 & 1.4 \\
\hline İş stresinden kurtulmak & 0,7 & 0,0 & 0.4 \\
\hline
\end{tabular}

Pearson Chi-Square Value 107,233a Df:8 *p $\leq 0.0001$

Rekreasyon kavramı konusunda; Öğretim elemanlarının \% 55'i, boş zamanlarda yapılan aktif ve pasif etkinlikler olarak tanımlarken, \% 15,3'ü piknik ve kır gezileri, \% $13^{\prime}$ ü eğlence ve \% $10^{\prime}$ u ise spor yapmak olarak tanımlamışlardır. Öğrencilerin ise \% 73,6'sı boş zamanlarda yapılan aktif ve pasif etkinlikler, \% 10,9'u spor yapmak, \% 4,8'i ise eğlence olarak belirtmiştir (Çizelge 4). Rekreasyon kavramı açısından öğretim elemanları ve öğrencilerin çoğunluğu boş zamanlarda yapılan aktif ve pasif etkinlikler şeklinde tanımlamış olup bilimsel tanıma uygun görüş bildirmişlerdir. Günümüzde bu kavramın aslında yaygın bir şekilde benimsendiği ve kullanıldığı görülmekle birlikte pek çok araştırmada (Tunçkol ve Çumralıgil, 2005) kavram konusunda henüz tam bilgiye sahip olunmadığı da görülmektedir.

Çizelge 4. Rekreasyon kavramı

\begin{tabular}{|c|c|c|c|c|}
\hline & & Öğretim Elemanları (\%) & Öğrenciler (\%) & Toplam (\%) \\
\hline \multirow{8}{*}{$\begin{array}{c}\text { Rekreasyon } \\
\text { kavramının anlamı }\end{array}$} & $\begin{array}{c}\text { Boş zamanlarda yapılan aktif ve pasif } \\
\text { etkinlikler }\end{array}$ & 59.3 & 73.6 & 66.5 \\
\hline & Spor yapmak & 10 & 10.9 & 10.5 \\
\hline & Eğlence & 13.3 & 4.8 & 9.1 \\
\hline & Piknik ve kır gezileri & 15.3 & 2.4 & 8.9 \\
\hline & Artık zaman & 0.7 & 4.5 & 2.6 \\
\hline & Gezmek & 1.3 & 2.4 & 1.9 \\
\hline & Seyahat etmek & 0 & 0.8 & 0.4 \\
\hline & Yeme-içme & 0 & 0.5 & 0.3 \\
\hline
\end{tabular}

Pearson Chi-Square Value 50,660a df:7 *p $\leq 0.0001$

Ankete katılanların rekreasyonel etkinlikleri tercih etmesinde etkili olan faktörler sorulduğunda; Öğretim elemanlarının \% 17,6'sı boş zaman varlığı, \% 14,7'si ortam koşulları ve \% 14,2'sinin ise ailesinin etkili olduğunu belirtmişlerdir. Öğrencilerin ise; \% 22,2'si arkadaş ortamı, \% 18,1'i boş zaman varlığı ve \% 8,6'sı ortam koşulları olduğunu belirtmiştir (Çizelge 5). Rekreasyonel etkinliklerde tercih edilmesinde etkili olabilecek faktörler açısından öğretim elemanları ve öğrencilerin çoğunluğu boş zaman varlığı ve arkadaş ortamının öncelikli olarak etkili olabileceğini belirtmiştir.

Çizelge 5. Rekreasyonel etkinliklerinin tercih edilmesinde etkili

\begin{tabular}{|c|c|c|c|c|}
\hline & & Öğretim Elemanları (\%) & Öğrenciler (\%) & Toplam(\%) \\
\hline \multirow{9}{*}{$\begin{array}{l}\text { Rekreasyonel Etkinlikleri tercih } \\
\text { etmede etkili faktörler }\end{array}$} & Yanıt vermeyenler & 36.4 & 35.4 & 36.0 \\
\hline & Boş zaman varlığı & 17.6 & 18.1 & 17.9 \\
\hline & Arkadaş ortamı & 10.0 & 22.2 & 16.2 \\
\hline & Ortam Koşulları & 14.7 & 8.6 & 11.7 \\
\hline & Ailem & 14.2 & 2.3 & 8.3 \\
\hline & Sağlık Durumu & 5.1 & 3.3 & 4.2 \\
\hline & İnternet & 1.3 & 6.2 & 3.8 \\
\hline & Moda & 0 & 1.7 & 0.9 \\
\hline & Yazılı medya & 0.7 & 0.7 & 0.7 \\
\hline
\end{tabular}




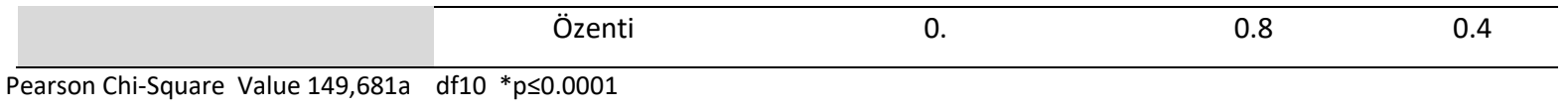

Rekreasyonel etkinliklerin temel amacı ne olmalıdır sorusuna; Öğretim elemanlarının \% 37,3'ü mutlu etmeli ve yaşama anlam katmalı derken, \% 26,7'sı dinlenme, eğlenme, huzur sağlamalı, \% 16,7'si ise stres atmada ve rahatlamada yardımcı olmalı, \% 12,7'si ise boş zamanları verimli ve kaliteli bir şekilde gerçekleştirmeli şeklinde belirtmişlerdir. Öğrencilerin ise; \% 52 'si dinlenme, eğlenme, huzur sağlamalı, \% 27,7'si mutlu etmeli ve yaşama anlam katmalı, \% 10,4'ü ise boş zamanları verimli ve kaliteli bir şekilde geçirilmesi gerektiğini vurgulamıştır (Çizelge.6).

Çizelge 6. Rekreasyonel etkinliklerin temel amacı

\begin{tabular}{|c|c|c|c|c|}
\hline & & Öğretim Elemanları (\%) & Öğrenciler(\%) & Toplam (\%) \\
\hline \multirow{6}{*}{$\begin{array}{c}\text { Rekreasyonel } \\
\text { Etkinliklerin Temel } \\
\text { Amacı }\end{array}$} & $\begin{array}{c}\text { Dinlenme, eğlenme ve huzur } \\
\text { sağlamalı }\end{array}$ & 26.7 & 52.0 & 39.33 \\
\hline & $\begin{array}{l}\text { Mutlu etmeli ve yaşama anlam } \\
\text { katmalı }\end{array}$ & 37.3 & 27.7 & 32.53 \\
\hline & $\begin{array}{l}\text { Bos zamanların verimli ve kaliteli } \\
\text { bir şekilde gerçekleştirmeli }\end{array}$ & 12.7 & 10.4 & 11.53 \\
\hline & $\begin{array}{c}\text { Stres atmada ve rahatlamada } \\
\text { yardımcı olmalı }\end{array}$ & 16.7 & 0.5 & 8.60 \\
\hline & $\begin{array}{c}\text { Psikolojik olarak yenilemeli ve } \\
\text { geliştirmeli }\end{array}$ & 6.7 & 2.9 & 4.80 \\
\hline & Eğitici ve öğretici olmalı & 0. & 6.4 & 3.20 \\
\hline
\end{tabular}

\subsection{Eğilimler}

Ankete katılanların serbest zamanlarında gerçekleştirdikleri genel rekreasyonel etkinlikler açısından; Öğretim elemanlarının \% 18,2'si internet veya bilgisayar ortamında vakit geçirdikleri, \% 14,7'si spor etkinlikleri, \% 13,1'i doğa ve çevre gezileri, \% 12,4'ü sinema-tiyatro gibi kültürel etkinliklerde ile uğraştıklarını ifade etmişlerdir. Öğrencilerin ise \% 22,2'si internet veya bilgisayar ortamında vakit geçirdikleri, \% 15,4'ü kâğıt oyunları, tavla, vb. gibi oyunlar oynayarak, \% 14,0'ü ise müzik dinleyerek vakit geçirdiklerini belirtmişlerdir. Genelde internet ve bilgisayar gibi sanal ortamda zaman geçirme giderek artan bir etkinlik haline geldiğini söylemek mümkündür (Çizelge.7).

Tunçkol ve Çumralıgil (2005) tarafından yapılan bir araştırmada Selçuk Üniversitesi'nde görevli akademik personelin \% 48,7 spor faaliyetleri, \%16,9' u kır gezileri, \% 4,8'i müzikle, \% 7'si kütüphaneye $\% 1,6^{\prime}$ sı el işi faaliyetleri ve \% $23,8^{\prime} i$ ise hepsi cevabını vermişlerdir. Rekreasyon faaliyetlerine katılan akademisyenlerin \% 60,3'ü bedensel faaliyetlerle uğraşırken, \% 19,6'sı müzikle, \% 7.4'ü resimle, \% 6,9'u bahçecilik \% 5,8'i internet ile uğraştıkları ifade edilmiştir. Pulur (2003); Kırıkkale 'de yaptığı anket çalışmasında görev yapan öğretim elemanlarının boş zamanlarının daha çok evlerinde dinledikleri ve kitap okudukları belirlenmiştir. Mete ve Ağaoğlu (2003)'na göre; Ondokuz Mayıs Üniversitesi ankete katılan akademik personelin yerleşkede yeterli imkân ve zaman olmadıkları için yerleşke dışında etkinliklerde bulundukları ifade edilmiştir. Kiper (2009) yaptıkları çalışmalarında açık alanlarda dolaşmak, müzik dinlemek, kitap okumak, Tv seyretmek gibi benzer sonuçlar görülmektedir. Tel ve Köksalan (2008); Doğu Anadolu Bölgesi'nde bulunan beş üniversitede görev yapan öğretim üyelerinin spor yapma alışkanlıkları konusunda yaptıkları araştırmada, erkek öğretim üyelerinin yürüyüş ve futbolu tercih ettiğini, bayan öğretim üyelerinin ise tercihlerini yürüyüş, halk oyunları ve modern danslardan yana kullandıklarını belirlemiştir.

Çizelge 7. Serbest zamanlarda en çok yapılan rekreasyonel etkinlikler

\begin{tabular}{ccccc}
\hline & & Öğretim Elemanları (\%) & Öğrenciler (\%) & Toplam (\%) \\
\hline Serbest & Internet-bilgisayar & 18.2 & 22.2 & 20.2 \\
\hline
\end{tabular}




\begin{tabular}{|c|c|c|c|c|}
\hline \multirow{14}{*}{$\begin{array}{c}\text { zamanlarda en çok } \\
\text { katılınan } \\
\text { rekreasyonel } \\
\text { etkinlikler }\end{array}$} & Kâğıt oyunları, okey, tavla vb. & 9.3 & 15.4 & 12.4 \\
\hline & Doğa ve çevre gezileri & 13.1 & 7.7 & 10.4 \\
\hline & Spor yapmak & 14.7 & 5.7 & 10.2 \\
\hline & Müzik dinlemek & 2.7 & 14.0 & 8.4 \\
\hline & Şehir içi mekânlarda vakit geçirmek & 11.3 & 4.4 & 7.9 \\
\hline & Sinema-tiyatro gibi kültürel etkinlikleri & 12.4 & 3.2 & 7.8 \\
\hline & Konser & 1.3 & 6.3 & 3.8 \\
\hline & Fotoğraf, resim & 1.1 & 6.0 & 3.6 \\
\hline & Kitap-gazete vb. okuma & 2.0 & 5.2 & 3.6 \\
\hline & Piknik & 4.7 & 1.6 & 3.2 \\
\hline & Yürüyüş yapma & 5.3 & 0.9 & 3.1 \\
\hline & Alışveriş yapmak & 3.1 & 1.3 & 2.2 \\
\hline & Tv seyretme & 0.2 & 3.7 & 2.0 \\
\hline & $\begin{array}{l}\text { Kişisel gelişimi tamamlayacak kurslara } \\
\text { katılmak }\end{array}$ & 0.2 & 2.4 & 1.3 \\
\hline
\end{tabular}

Boş zamanlarda hobi olarak; Öğretim elemanlarının \% 20'si teknolojik uğraşlarla vakit geçirirken, \% 16,7 'si seyahat etmek, \% 16.0'sı sportif aktivitelerde bulunmaktadır. Öğrencilerin \% 22,9'u seyahat etmek, \% 18,4'ü sportif aktivitelerde bulunmak, \% 16,5'u teknolojik uğraşılar, \% 11,5'i de sinema ve tiyatro gibi kültürel etkinliklerde bulundukları ifade edilmiştir (Çizelge 8).

Kır (2007); boş zamanın, bireyin kişiliğinin gelişmesinde, toplumsal refah ve kalkınmanın sağlanmasındaki rolüne dikkat çekerek, üniversite öğrencilerinin pasif boş zaman değerlendirme alışkanlıklarının, ülke refahının artmasına katkı sağlamaktan uzak olduğunu, bunun yanında gençlerin kimlik gelişimlerini de olumsuz etkileyebileceğini bildirmiştir. Araştırmacı çalışmasında, yükseköğretim öğrencilerinin \% 44,4'ünün boş zamanlarında ders dışı kitap, dergi, gazete okuduğunu, \% 11.5'inin dinlendiğini, \% 10.3'ünün ise televizyon seyrettiğini saptamıştır. Boş zamanlarda spor yapma, kantinde arkadaşlarıyla sohbet etme, müzikle uğraşma, karşı cinsten bir arkadaşla gezme, kahveye gitme gibi faaliyetlerin öğrencilere fazla cazip gelmediğini saptamıştır. Terzioğlu ve Yazıcı (2003), üniversite öğrencilerinin boş zamanlarını değerlendirme anlayış ve alışkanlıkları ile ilgili Atatürk Üniversitesi'nde 1000 gönüllü ile yaptıkları çalışmada, öğrencilerin çok fazla boş zamanlarının olduğu, ancak bunu çok etkin değerlendiremedikleri; bütün öğrencilerin boş zaman ve sporu bedensel ve zihinsel gelişim aracı olarak görme düşüncesinde birleştiği belirlenmiştir. Balcı ve illhan (2006), Türkiye'deki yedi coğrafi bölgeden seçilen yedi üniversiteden 1318 öğrenci ile yaptıkları çalışmada, üniversitelerin rekreasyon programlarına katılan öğrencilerin, \%22.5'inin ilk sırada futbol ve ikinci sırada \%9.5'inin fitness branşlarını seçtiklerini, daha sonraki sıralarda ise müzik dinleme (\%14.1), tavla oynama (\%11.6) ve bilgisayar kullanma (\%19.6) aktivitelerinin yer aldığı saptanmıştır.

Çizelge 8. Hobiler

\begin{tabular}{|c|c|c|c|c|}
\hline & & Öğretim Elemanları (\%) & Öğrenciler (\%) & $\begin{array}{l}\text { Toplam( } \\
\%)\end{array}$ \\
\hline \multirow{6}{*}{ Genel hobiler } & Seyahat etmek, gezmek & 16.7 & 22.9 & 19.8 \\
\hline & Teknolojik uğraşlar(tv, bilgisayar, telefon, vb) & 20.0 & 16.5 & 18.2 \\
\hline & Sportif aktivitelerde bulunmak & 16.0 & 18.4 & 17.2 \\
\hline & Sinema ve tiyatro gibi kültürel etkinliklerde bulunmak & 6.7 & 11.5 & 9.1 \\
\hline & Aile ile vakit geçirmek, arkadaşlarla vakit geçirmek & 13.2 & 4.3 & 8.7 \\
\hline & Gazete, dergi ve kitap okumak, resim yapmak vb & 4.7 & 8.3 & 6.5 \\
\hline
\end{tabular}






Pearson Chi-Square Value 57,078a df $9{ }^{*} p \leq 0.0001$

SDÜ yerleşkesinde dış mekân rekreasyonel etkinliklere öğretim elemanlarının \% 17,3'ü öğrencilerin ise \% 37,1'inin katıldığı belirlenmiştir (Çizelge.9). Sonuçta çoğunlukla kapalı mekânlarda rekreasyonel etkinliklerin yapıldığı ortaya çıkmaktadır. SDU yerleşkesinde öğrencilerin açık mekânlarda vakit geçirenlerin düşük olmasının nedeni peyzaj rekreasyonel mekânlarının yetersiz olmasıdır. Mansuroğlu (2002) Akdeniz Üniversitesi Yerleşkesinde ise öğrencilerin \% 43.5'i dış mekân rekreasyon etkinliklerine katıldığı ve ayrı bir çalışmada ise Yerlisu Lapa ve Ardahan, (2009) Akdeniz Üniversitesi öğrencilerin\% 55.2'sinin yerleşkedeki açık-kapalı alanlarda vakit geçirdikleri (özellikle \% 31'i Olbia çarşı mekânında \% 20 si ise Fakülte kantinlerinde) belirtmiştir.

Yerleşkede rekreasyonel etkinliklere katılma nedeni sorulduğunda; Öğretim elemanlarının \% 37,3'ünün mutlu olmak için, \% 11,3'ünü arkadaşlarla beraber olmak ve eğlenmek için \% 10,7'si ise yeni beceriler kazanmak için cevabını vermiştir. Öğrencilerin ise \% 59,7'i mutlu olmak için, \% 19,5'nin arkadaşlarla beraber olmak için, \% 11,7'sinin dinlendirici olduğu için rekreasyonel etkinliklere katıldıklarını belirtmişlerdir (Çizelge 9). Öğrenciler rekreasyonel aktivitelerde arkadaşları ile bir arada olabilecekleri, toplu olarak katılım gösterilebilecekleri ve sosyal yönü zengin etkinlikleri tercih etmektedirler. Bu kapsamda da sportif, kültürel-sosyal ve doğaya yönelik olarak yapılan etkinliklere karşı ilgileri daha fazla olmuştur. Mansuroğlu (2002) ile Yerlisu Lapa ve Ardahan (2009) tarafından yapılan Akdeniz Üniversitesi Yerleşkesinde yaptığı anket çalışmasında öğrencilerin rekreasyon etkinliklerine katılma nedenlerinin başında eğlenmek, rahatlamak, stres azaltmak ve arkadaşlarla beraber olmak ve sağlıklı olmak vb gelmektedir. Önder (2003) yaptığı çalışmada yerleşkede rekreasyonel etkinliklerde kişinin sıkıntısı atması, mutlu olmak, arkadaşlarla beraber olmak ve dinlenmek amaçlı yapıldığı ifade etmektedir. Üniversite öğrencilerinin boş zaman değerlendirmesinde daha çok arkadaşlarıyla birlikte olmak istediğini, güzel bir ortam olduğu için boş zaman etkinliklerine katıldıklarını, büyük çoğunluğu dinlendirici, rahatlatıcı, iş stresinden uzaklaştırıcı etkisi olduğunu belirlemiştir (Göktaş ve Çolak 2006 Yetiş 2008; Tekin vd., 2007). Huang and Carleton(2003) üniversite öğrencilerine yaptıkları bir çalışmada rekreasyonel aktivitelere katılımın gençlerin yaşam doyumunu artırdığını belirlemişlerdir.

Çizelge 9. Rekreasyonel etkinliklere katılma nedenleri

\begin{tabular}{|c|c|c|c|c|}
\hline & & Öğretim Elemanları (\%) & Öğrenciler (\%) & Toplam (\%) \\
\hline \multirow{10}{*}{$\begin{array}{c}\text { Yerleşkede } \\
\text { Rekreasyonel } \\
\text { Etkinliklerine } \\
\text { Katılma Nedenleri }\end{array}$} & Mutlu olmak için & 37.3 & 59.7 & 48.5 \\
\hline & Arkadaşlarla beraber olmak ve eğlenmek için & 11.3 & 19.5 & 15.4 \\
\hline & Dinlendirici olduğu için & 5.3 & 11.7 & 8.5 \\
\hline & Sıkıntıdan kurtulmak için & 12 & 0 & 6.0 \\
\hline & Çevre edinmek için & 8 & 3.2 & 5.6 \\
\hline & Yeni beceriler kazanmak için & 10.7 & 0 & 5.3 \\
\hline & Bilgi ve kültür arttırmak için & 6.7 & 3.5 & 5.1 \\
\hline & Eğitmesi için & 6.0 & 0.5 & 3.2 \\
\hline & Sağlık için & 2.7 & 0.3 & 1.5 \\
\hline & Yalnız kalmamak için & 0.0 & 1.6 & 0.8 \\
\hline
\end{tabular}

Rekreasyonel etkinliklere katılmama nedenleri için; Öğretim elemanlarının \% 40,7'si zaman darlığı, \% $25,3^{\prime}$ i mevcut ortamın uygun olmaması, \% 22,7'si faaliyetler konusunda bilgi sahibi olunmaması 
konusunda yanıtlamışlardır. Öğrencilerin ise \% 38,1'i maddi yetersizlikler, \% 16,8'si zaman darlığı, \% 13,3 ü alışkanlıkların olmaması ve \% 10,7'si de mevcut ortamın uygun olmamasından dolayı rekreasyonel etkinliklere katılamadıkları ifade edilmiştir (Çizelge.10). Mansuroğlu (2002) ile Yerlisu Lapa ve Ardahan (2009) tarafından Akdeniz Üniversitesi Yerleşkesinde yapılan anket çalışmasında öğrencilerin dış mekân rekreasyon etkinliklerine katılamama nedeni olarak zaman yetersizliği, etkinlik saat ve günlerin uygun olmaması, olanaksızlıklar, para yetersizliği ve iletişim eksikliği şeklinde sıralanmıştır.

Anket sonuçlarına göre; Öğretim elemanlarının rekreatif etkinliklere ayırabilecek çok fazla zamanlarının olmadıkları, öğrencilerin ise rekreatif etkinliklere ayırabilecek serbest zamana sahip oldukları, ancak serbest zamanlarını değerlendirme konusunda da yetersiz oldukları belirlenmiştir. Genellikle öğrencilerin rekreasyonel etkinliklere katılmama nedenlerinin temel sebebinin maddi durumların yeterli olmayışı olduğu görülmektedir. Öğrenciler için maddi imkânsızlıklar ve tesis eksikliği gibi benzer sonuçlar Mansuroğlu (2002), Önder (2003), Günaydın vd. (2012), Kiper (2009) ve Sabbağ ve Aksoy, (2011) tarafından yapılan çalışmalarda da görülmektedir. Süzer (1997)'in yaptığı çalışmada; öğrencilerin serbest zaman faaliyetlerine katılmalarında ellerine geçen para miktarının önemli etkisi olduğunu ve öğrencilerin ellerine geçen para miktarı arttıkça serbest zaman faaliyetleri için harcadıkları para miktarının da arttığını ortaya koymuştur.

Öğrencilerin serbest zamanlarını nerede ve ne şekilde geçireceklerini bilememeleri yerleşke içerisindeki mevcut alanların ve eğitim eksikliğinden kaynaklanmaktadır. Cardinal et al. (2002)'nin rekreasyonun yararlarına yönelik; $A B D^{\prime}$ 'de üniversite öğrencileri ile yapılan bir çalışmasında her beş öğrenciden birinin fazla kilolu olduğu ve bunların herhangi bir aktivite ile uğraşmadıkları ya da çok az efor sarf ettiren aktiviteleri tercih ettikleri belirlenmiştir. Bu nedenle ABD üniversitelerinin \% 63'ünde öğrencilerin mezun olabilmek için bazı fiziksel aktivite kurslarından geçmeleri istenmektedir. Bu sistemin, genel anlamda öğrencilerin davranış ve alışkanlıklarını olumlu yönde değiştirdiği saptanmıştır (Rowland,1996; Kiper, 2009).

Yerleşke içerisindeki mekânsal ulaşımın yetersiz olması rekreasyonel etkinliklere olan talebin düşük olmasına neden olan diğer bir sorundur. Akademisyenler genellikle kendi şahsi odalarında zaman geçirmekte öğrenciler ise bölüm kantinleri, kütüphane gibi kapalı alanlarda öncelikli olarak zamanları değerlendirmektedirler. Öncelikli olarak etkinliklerde fiziksel, uygulamalı, kültürel, sanatsal ve sportif etkinlikleri olması tercih edilmektedir.

Çizelge 10. Rekreasyonel etkinliklere katılmama nedenleri

\begin{tabular}{lcccc}
\hline & Zaman darlı̆̆ı & Öğretim Elemanları(\%) & Öğrenci (\%) & Toplam (\%) \\
\hline & Maddi yetersizlikler & 40.7 & 16.8 & 28.75 \\
\cline { 2 - 5 } & $\begin{array}{c}\text { Faaliyetler konusunda bilgim } \\
\text { olmaması }\end{array}$ & 2.0 & 38.1 & 20.05 \\
\cline { 2 - 5 } $\begin{array}{c}\text { Yerleşkede } \\
\text { Rekreasyonel } \\
\text { Etkinliklere Katılamama } \\
\text { Nedenleri }\end{array}$ & Mevcut ortamın uygun olmaması & 22.7 & 9.6 & 16.15 \\
\cline { 2 - 5 } & Alışkanlığım olmadığı için & 9.3 & 10.7 & 11.3 \\
\cline { 2 - 5 } & Etkinlik sayısının azlığı & 0 & 13.3 & 2.8 \\
\cline { 2 - 5 } & Ulaşım zorluğu & 0 & 3.6 & 1.7 \\
\hline
\end{tabular}

Yerleşkede haftada ortalama bulunma günlerine göre; Öğretim elemanlarının \% 90,7'si 5 gün, \% 9,3'ü 4 gün kalırken öğrencilerin \% 36,5'i 3 gün, \% 33,1'i 5 gün yerleşkede bulundukları ifade edilmiştir. Ayrıca günde ortalama bulunma sürelerine göre; Öğretim elemanlarının \% 50'si 6-8 saat ve \% 47,3'ü ise 4-6 saat kalırken, öğrencilerin ise \% 42,7'si 4-6 saat ve \% 24,3'ü ise 2-4 saat arasında yerleşkede zaman geçirdiklerini belirtmiştir (Çizelge.11). Öğretim elemanlarının ve öğrencilerin haftada ortalama 4 veya 3 gün yerleşkede bulunduğu ve günlük zamanlarının en az 4-6 saatlerini üniversitede 
geçirdikleri belirlenmiştir. Aslında en önemli sonuçlardan birisi genelde hafta içi kullanılan SDU yerleşkesi hafta sonları ne yazık ki kullanılmamasıdır. Ayrıca Yerleşke içinde serbest zamanların etkin kullanmaya vakitlerinin yeterli olduğu ancak nasıl kullanılması gerektiğini bilmedikleri de görülmektedir.

Mansuroğlu (2002), Akdeniz Üniversitesi Yerleşkesinde öğrencilerin hafta içi günlük 5 saat hafta sonu ise 10 saat serbest zamana sahip olduğunu belirtmiştir. Öğrencilerin Üniversite Yerleşkelerinde bulundukları süre ve kent merkezinde geçirilen süre açısından rekreasyonel aktivitelere katılımlarının da özellikle etkili olduğu belirlenmiştir (Müderrisoğlu ve Uzun, 2004).

Çizelge 11. Haftada ve günde ortalama yerleşkede bulunma süresi

\begin{tabular}{|c|c|c|c|c|}
\hline & & Öğretim Elemanları (\%) & Öğrenci(\%) & Toplam(\%) \\
\hline \multirow{5}{*}{$\begin{array}{l}\text { Yerleşkede bulunma süresi } \\
\text { (Haftada ortalama gün sayısı) }\end{array}$} & 5 gün & 90.7 & 33.1 & 61,9 \\
\hline & 3 gün & 0 & 36.5 & 18,2 \\
\hline & 4 gün & 9.3 & 21.6 & 15,4 \\
\hline & 2 gün & 0 & 5.6 & 2,8 \\
\hline & 1 gün & 0 & 3.2 & 1,6 \\
\hline \multirow{5}{*}{$\begin{array}{c}\text { Yerleşkede günlük bulunma } \\
\text { süresi (Günlük ortalama saat } \\
\text { süresi ) }\end{array}$} & $6-8$ saat & 50.0 & 21.1 & 35.5 \\
\hline & 4-6 saat & 47.3 & 42.7 & 45.0 \\
\hline & 2-4 saat & 0 & 24.3 & 12.1 \\
\hline & 8 saat $<$ & 2.7 & 7.7 & 5.2 \\
\hline & $<2$ saat & 0 & 4.3 & 2.1 \\
\hline
\end{tabular}

Pearson Chi-Square Value 144,939a df $4{ }^{*} p \leq 0.0001$

Yerleşke içerisindeki mekânsal ulaşılabilirlik konusunda; Öğretim elemanlarının \% 55,3'ü ulaşımın yetersiz olduğunu, öğrencilerin \%60'। ise kısmen yeterli olduğunu belirtmiştir (Çizelge 12).

Çizelge 12. Yerleşke içerisi ulaşılabilirlik

\begin{tabular}{ccccc}
\hline & & Öğretim Elemanları (\%) & Öğrenci(\%) & Toplam(\%) \\
\hline $\begin{array}{c}\text { Yerleşke içerisinde mekânsal } \\
\text { ulaşılabilirlik (yaya ulaşımı olarak) } \\
\text { yeterliliği }\end{array}$ & Hayır & 55,3 & 22,7 & 51,6 \\
\cline { 2 - 5 } & Kısmen & 30,7 & 60,0 & 32,0 \\
\hline Pearson Chi-Square Value 54,316a df $2{ }^{*} p \leq 0.0001$ & 14,0 & 17,3 & 16,4 \\
\hline
\end{tabular}

Yerleşke içerisinde vakit geçirilen mekânlar sorulduğunda; Öğretim elemanlarının \% 52,7'si kişisel odalarında, \% 10,7'si Fakülte kantinlerinde, \% 10'u ise Merkezi dersliklerdeki kantin ve çevresinde vakit geçirmekte, öğrencilerin ise \% 60,5'i Fakülte kantinlerinde, \% 22,4'ü Merkezi dersliklerdeki kantin ve çevresinde ve \% 9,9 ise kütüphane de vakit geçirmektedir (Çizelge.13).

Çizelge 13. Yerleşke içerisinde en çok vakit geçirilen mekânlar

\begin{tabular}{|c|c|c|c|c|}
\hline & & Öğretim Elemanları (\%) & Öğrenci (\%) & Toplam (\%) \\
\hline \multirow{6}{*}{$\begin{array}{c}\text { Yerleşke } \\
\text { içerisinde en çok } \\
\text { vakit geçirilen } \\
\text { yerler }\end{array}$} & Fakülte kantinleri & 10.7 & 60.5 & 35.6 \\
\hline & Kişisel oda & 52.7 & 0 & 26.3 \\
\hline & $\begin{array}{c}\text { Merkezi dersliklerdeki kantin ve } \\
\text { çevresi }\end{array}$ & 10.0 & 22.4 & 16.2 \\
\hline & Kütüphane & 3.3 & 9.9 & 6.6 \\
\hline & Tenis kortu & 7.3 & 1.3 & 4.3 \\
\hline & Yerleşke içi yeşil alanlar & 4.0 & 3.5 & 3.7 \\
\hline
\end{tabular}




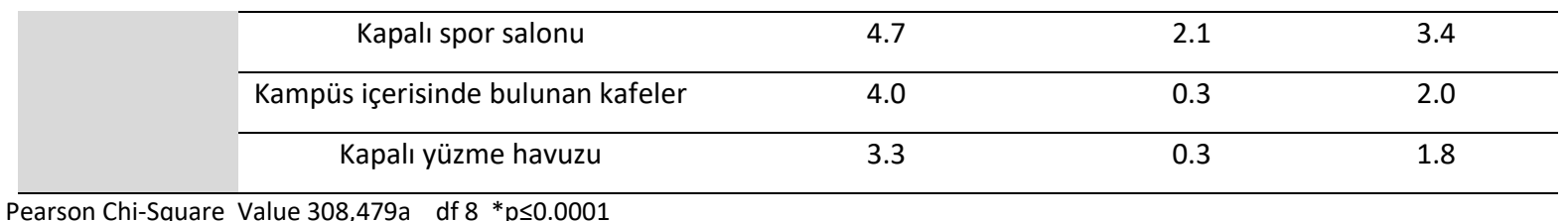

\subsection{Talepler ve Yorumlar}

Yerleşke içerisinde mevcut açık ve yeşil alanların yeterliliği sorulduğunda; Genel olarak öğretim elemanlarının \% 95,3'ü ve öğrencilerin ise \% 63,7'si açık ve yeşil alanların kesinlikle yeterli olmadığı ifade edilmiştir (Çizelge.14).

Çizelge 14. Mevcut açık yeşil alanların yeterliliği

\begin{tabular}{|c|c|c|c|c|}
\hline & & Öğretim Elemanları (\%) & Öğrenci (\%) & Toplam (\%) \\
\hline \multirow{2}{*}{$\begin{array}{l}\text { Yerleşke içerisindeki mevcut açık yeşil alan } \\
\text { yeterliliği }\end{array}$} & Hayır & $95,3 \%$ & $63,7 \%$ & $72,8 \%$ \\
\hline & Evet & $4,7 \%$ & $36,3 \%$ & $27,2 \%$ \\
\hline
\end{tabular}

Yerleşkede öncelikli olarak rekreasyonel etkinliklerin olması konusunda; Öğretim elemanlarının \% 33,3'ü fiziksel etkinlikler, \% 29,3'ü entelektüel ve kültürel ortamların oluşturulmasını, \% 17,3 ü bilimsel ve kişisel gelişim etkinlikleri arzu ederken, öğrencilerin ise \% $24,5^{\prime}$ i fiziksel etkinlikler, \% $21,3^{\prime}$ ü sportif etkinlikler, \% 16,8'i bilimsel ve kişisel gelişim etkinliklerin olmasını talep etmişlerdir (Çizelge.15).

Çizelge 15. Yerleşkede olması istenilen etkinlikler

\begin{tabular}{lcccc}
\hline & & \multicolumn{1}{c}{$\begin{array}{c}\text { Öğretim Elemanları } \\
\text { (\%) }\end{array}$} & Öğrenci (\%) & Toplam (\%) \\
& Fiziksel Etkinlikler & 33.3 & 13.3 & 23.3 \\
\cline { 2 - 5 } & Sanatsal Etkinlikler & 16.0 & 24.5 & 20.3 \\
\cline { 2 - 5 } $\begin{array}{c}\text { Yerleşkede olması istenile } \\
\text { etkinlik tercihleri }\end{array}$ & Entelektüel ve kültürel etkinlikler & 29.3 & 9.1 & 19.2 \\
\cline { 2 - 5 } & Bilimsel ve Kişisel Gelişim Etkinlikleri & 17.3 & 16.8 & 17.1 \\
\cline { 2 - 5 } & Sportif & 4 & 21.3 & 12.7 \\
\cline { 2 - 5 } & Düşünsel & 0 & 8.5 & 3.3 \\
\hline
\end{tabular}

Pearson Chi-Square Value 97,721a df $6{ }^{*} p \leq 0.0001$

Yerleşke içinde açık alan rekreasyonel etkinlikler ve bu etkinliklerinin yapılacağı mekânlar nelerdir sorusuna; Öğretim Elemanlarının \% 32,0'u dinlenme ve oturma mekânları, \% 20,7'si yürüyüş ve koşu parkurları, \% 16,0'si bisiklet yolu, \% 15,3'ü sportif etkinlik alanlarının olmasını istenmiştir. Öğrenciler ise \% 28,5'i dinlenme ve oturma mekânları, \% 22,7'si yürüyüş ve koşu parkurları, \% 22,4'ü bisiklet yolu ve \% 11,2'si ise sportif etkinlikleri olmasını talep etmişlerdir (Çizelge 16.).

Çizelge 16. Açık alan rekreasyonel aktiviteler ve yapılacağı alanlar

\begin{tabular}{ccccc}
\hline & & Öğretim Elemanları (\% & Öğrenci (\%) & Toplam (\%) \\
\hline & Dinlenme ve Oturma Alanları & 32.0 & 28,5 & 30,3 \\
\cline { 2 - 5 } & Yürüyüş Ve Koşu Parkuru & 20,7 & 22,7 & 21,7 \\
\cline { 2 - 5 } & Bisiklet Yolu & 16,0 & 22,4 & 19,2 \\
\hline $\begin{array}{c}\text { Yerleşkede açık } \\
\text { rekreasyon ala } \\
\text { tercihleri }\end{array}$ & Sportif Etkinlik Alanları & 15,3 & 11,2 & 13,3 \\
\cline { 2 - 5 } & Sus Havuzları Ve Görsel Oyunlar & 11,3 & 6,1 & 3,7 \\
\cline { 2 - 5 } & Acık Alanda Kitap Okuma & 2,0 & 5,1 & 3,6 \\
\cline { 2 - 5 } & Acık Hava Sinema Salonu & 2,7 & 1,6 & 2,2 \\
\hline
\end{tabular}




\begin{tabular}{cccc}
\hline Hava Sporları & 0,0 & 0,3 & 0,2 \\
\hline Tırmanma Duvarı & 0 & 1,6 & 0,8 \\
\hline Acık Jimnastik Alanı & 0 & 0,5 & 0,3 \\
\hline
\end{tabular}

Pearson Chi-Square Value 14,689a df $9{ }^{*} p \leq 0.1$

Yerleşke içinde rekreasyonel amaçlı kapalı mekânlar konusunda; Öğretim elemanlarının \% 73,3'ü çok amaçlı çarşı merkezi, \% 13,3'u kafe ve restoran, \% 7,3'ü tiyatro- sinema ve konser salonu ve oditoryum gibi mekânlar talep edilmiştir. Öğrenciler ise \% 48,8'i çok amaçılı çarşı merkezi, \% 20,0'si kafe ve restoran, \% 8,0'i ise hobi ve öğrenci kulüplerinin gibi olmasını belirtmişlerdir (Çizelge 17).

Çizelge 17. Kapalı alanda olması istenen rekreasyonel aktiviteler ve alanlar

\begin{tabular}{ccccc}
\hline & Çok Amaçlı Çarşı Merkezi & Öğretim Elemanları (\%) & Öğrenci (\%) & Toplam (\%) \\
\hline & Kafe ve Restoran & 73.3 & 48,8 & 61.1 \\
\cline { 2 - 5 } & $\begin{array}{c}\text { Tiyatro- Sinema, Konser Salonu ve } \\
\text { Oditoryum }\end{array}$ & 73.3 & 20.0 & 16.7 \\
\cline { 2 - 5 } $\begin{array}{c}\text { Yerleşke içinde } \\
\text { rekreasyonel amaçlı } \\
\text { kapalı mekân } \\
\text { tercihleri }\end{array}$ & Eğlence- Oyun Merkezi & 6.3 & 6.9 \\
\cline { 2 - 5 } & Hobi ve Öğrenci Kulüpleri & 6.0 & 4.5 & 5.3 \\
\cline { 2 - 5 } & Internet ve Oyun Salonları & 0 & 8.0 & 3.5 \\
\cline { 2 - 5 } & Kapalı Spor Kompleksi & 0 & 6.9 & 2.3 \\
\hline
\end{tabular}

Ankete katılan öğretim elemanları ve öğrencilere "Üniversite Rektörü olsanız hangi rekreasyonel faaliyetler olarak öncelikleriniz ne olurdu? sorusuna öğretim elemanlarının ve öğrencilerin büyük çoğunluğu sosyal ve çarşı mekânları, yeşil alanlarının artırıması, araç ve yaya ulaşımının düzenlenmesi, sportif alanların artırılması, sosyal ve kültürel etkinliklerin artırılması, bisiklet yollarının yapılması vb şeklinde sıralanmıştır (Çizelge 18.).

Çizelge 18. Ankete katılanların Rektör olması durumunda rekreasyonel faaliyet öncelikleri

\begin{tabular}{cccc}
\hline $\begin{array}{c}\text { Üniversite Rektörü Olunması durumunda Yerleşkede } \\
\text { Rekreasyonel Açıdan Yapılacak Öncelikli Faaliyetler? }\end{array}$ & Öğretim Elemanları (\%) & Öğrenci (\%) & Toplam (\%) \\
\hline Sosyal ve çarşı mekânı açmak & 81 & 75 & 17.3 \\
\hline Yeşil alanların nitelik ve niceliklerini artırmak & 71 & 73 & 16.0 \\
\hline Araç ve yaya ulaşımı yeniden düzenlenek & 70 & 45 & 12.8 \\
\hline Sportif alanlar ve etkinlikleri artırmak & 46 & 68 & 12.7 \\
\hline Sosyal ve kültürel etkinliklere önem vermek & 51 & 48 & 11.0 \\
\hline Koşu ve Bisiklet yolu yapmak & 42 & 46 & 9.8 \\
\hline Otopark düzenlemesine önem vermek & 35 & 12 & 5.2 \\
\hline Eğlence mekânlarını artırmak & 15 & 21 & 4.0 \\
\hline Öğrenci kulüplerini daha aktif hale getirmek & 5 & 21 & 2.9 \\
\hline Kişisel gelişimi sağlayacak aktiviteler düzenlemek & 5 & 15 & 2.2 \\
\hline Yarışma ve turnuvalar düzenlenmek & 7 & 9 & 1.8 \\
\hline Yerleşke güvenliğini sağlanmak & 6 & 8 & 1.6 \\
\hline Çeşitli rekreasyonel kurslar düzenlemek & 5 & 5 & 1.1 \\
\hline Kent insanına yönelik etkinlikler yapmak & 7 & 1 & 0.9 \\
\hline
\end{tabular}




\section{Sonuç ve Öneriler}

Günümüzde üniversite yerleşkeleri, eğitim-öğretim ve bilimsel çalışmalarının yürütüldüğü mekânlar olması yanı sıra rekreasyonel, sosyal, ekolojik ve ekonomik açısından çok yönlü işlevleri olan önemli yaşam mekânlarıdır. Dolayısıyla bu çalışma ile tespit edilenler; SDU Yerleşkesinde rekreasyonel talep ve beklentilerinin dikkate alınarak Yerleşke mekânlarının planlama \& tasarım ve yönetim çalışmalarına ışık tutması, üniversiteye hizmet verenler ve hizmet alanlar açısından serbest zamanlarının daha verimli ve aktif kullanmalarını sağlanması açısından yarar sağlayacaktır.

Sonuç olarak; SDU öğretim elemanları ve öğrencilerinin yerleşke içinde serbest zamanlarını daha çok kapalı mekânlarda geçirdikleri, serbest zamanı değerlendirmede genelde hafta içi olmak üzere ortalama 3 veya 4 günlük sürede rekreasyonel faaliyetlerde bulunulduğu ve öğretim elemanları ve öğrencilerin farklı rekreasyonel eğilimleri ve taleplerinin olduğu belirlenmiştir. SDU Yerleşkesinde çok amaçlı kapalı spor salonu, olimpik yüzme havuzu, açık spor oyun alanlarının (basketbol, tenis kortları vb) olması, önemli bir avantaj olarak görülmektedir. Öğretim elemanları ve öğrenciler tarafından özellikle Fakülte kantinleri, Merkezi derslik kantini ve çevresi ve kapalı spor mekânları yaygın olarak kullanılan mekânlardır. Yerleşkenin dış mekânları ise rekreasyonel tesis, mekân ve etkinliklerin yeterli ve tatmin edici düzeyde olmadığı ortaya çıkmıştır. Ayrıca rekreasyonel açısından mekânsal organizasyonu ve yönetişimin de etkin ve yeterli düzeyde olmadığı da belirlenmiştir. Bununla birlikte yeme içme alışveriş yapılacak çarşı konseptinde mekânların olmaması, kafe ve restoran gibi sosyal mekânlar ile dış mekân oturma ve dinlenme gibi mekânlarının olmaması, fakültelerdeki kantinlerin hizmet kalitesi ve süresinin tatmin edici olmaması vb. önemli eksikliklerin de olduğu belirlenmiştir.

Bu çalışmada Süleyman Demirel Üniversitesi Yerleşkesinde öğretim elemanları ve öğrencilerin kavramsal yaklaşımları, rekreasyonel eğilimler ve talepler belirlenerek çeşitli çözüm önerileri getirilmiştir.

- Üniversite yerleşkelerinde akademik ve idari personelin iş verimini artırmak, öğrencilerin eğitim ve öğretimin bir parçası olarak kendilerinin bir birey olarak öz güvenlerini artırmak, sosyalleştirmek, fiziksel ve zihinsel gelişmelerini sağlamak, çok amaçlı ihtiyaçların karşılanması için yerleşkelerde rekreasyon yönetim ve organizasyonun yapılmasını zorunlu kılmaktadır. Bu nedenle Amerika da başta olmak üzere gelişmiş ülkelerdeki yerleşkelerde oluşturulan "Rekreasyonel Yönetim Birimi" ile etkin ve yetkin bir şekilde önemli bir rol üstlenmektedir. Bu kapsamda Yerleşkede SDU Sağlık Kültür ve Spor (SKS) Daire Başkanlığı içinde "Rekreasyon Yönetim Birimi" oluşturulmalı ve ilgili ve farklı disiplinlerden oluşacak ekiple bütüncül organizasyon ve etkin faaliyetler yapılmalıdır.

- SDU Yerleşkesinde öncelikle uzun vadeli ve bütüncül mekânsal planlaması yapılmalıdır. Yerleşke içinde yeni yapılacak mimari projelerinin aynı zamanda peyzaj tasarım projeleri ile birlikte eşzamanlı olarak yapılmalıdır. Yerleşke peyzaj mekânlarının bütüncül organizasyonu, projelendirme, uygulama, bakım ve onarım çalışmaları tek birim tarafından yapılmalı, nicelik ve nitelik olarak kapasiteleri geliştirilmelidir. Bu birimde başta Peyzaj Mimarları olmak üzere ilgili disiplinlerden teknik personel çalıştırımalıdır.

- Yerleşke içinde yeşil alan içinde görsel ve işlevsel amaçlara uygun olabilecek bitkisel tasarım öngörülmelidir.

- $\quad$ Yerleşke içinde araç ve yaya ulaşımı sistemi daha etkin çözümler oluşturulmalı ve otoparklarla ilişkilendirilmesi gerekmektedir. Hatta personel ile öğrenci-ziyaretçi otopark alanları birbirlerinden ayrılmalıdır.

- Yerleşke güvenliğin ve kontrolün sağlanması ve sürekliliği için mümkün olduğunca Yerleşkeye az sayıda giriş noktası oluşturulmalıdır. Yerleşkede kent insanın kullanımına açık olan mekânlar (Hastane Araştırma ve Uygulama Hastanesi, Diş hekimliği gibi) yerleşke dışından girişlerin yapılması sağlanmalıdır.

- Ulaşımda yaya öncelikli düşünülerek yaya ve bisiklet yolları tasarlanmalı ve yerleşke içinde bisiklet ile ulaşım yaygınlaştırılmalıdır. 
- $\quad$ Engelli ulaşımı ve erişilebilirliği öncelikli olarak ele alınmalıdır.

- Yerleşke içerisinde talepleri doğrultusunda bisiklet yolları, paten alanları, süs havuzları ve görsel elemanlar, suni gölet, sportif aktivite alanları, yürüyüş ve koşu parkurları, macera oyun alanları rekreasyonel etkinliklere imkân sağlayabilecek mekânlar tasarlanmalıdır.

- $\quad$ SDU yerleşkesinde geçirilen kalma süresi ne kadar artırılırsa rekreasyonel faaliyetlere katılım ve yoğunluğun doğru orantılı olarak artmasına yol açacaktır. Bu nedenle Yerleşkede hafta içi ve sonları olmak üzere 24 saatlik yaşam dikkate alınarak Yerleşkede mekânsal düzenlemeler ve organizasyonlar yapılması sağlanmalıdır. Bununla birlikte özellikle hafta sonları rekreasyonel faaliyetlere katılımın sağlanmasına öncelik verilmelidir.

- $\quad$ Yerleşkede aslında en önemli eksikliklerinden birisi olarak nitelendirilen ve yerleşke içinde 24 saat çok yönlü ihtiyaçların karşılanabileceği çarşı konsepti mekânların hem doğu hem de batı yerleşkesi içinde öngörülmelidir.

- Yaya yolları ve oturma mekânlarında uygun süs havuzları veya hareketli su ögeleri kullanılmalı ve bitkilerle zenginleştirilmelidir.

- $\quad$ Yerleşke içerisinde öğrencilerin dinlenmelerine imkân verecek dinlenme elemanlarına ve peyzaj donatı ve mobilyalara (pergola, bank, çeşme, bitki kasaları, yer döşeme malzemeleri, aydınlatma elemanları gibi) yer verilmelidir.

- $\quad$ Yerleşkenin her yerinde bilgilendirme ve yönlendirme levhaları konulmalıdır.

- Her Fakülte binasına yakın ( en fazla 10 dk. mesafede) dış mekânında kapalı veya açık oturma ve dinlenme mekânları oluşturulmalıdır. Üniversite yerleşkelerinde dış mekân kullanımlarına ait açık alan tipleri bilimsel, kültürel, fonksiyonel ve estetik amaçıı olarak kullanılabilir şekilde tasarlanmalıdır.

- Eğlence, konser, bilimsel etkinlikler gibi öğrencilerin toplanmasına yönelik alanlar ve "landmark" alanlar oluşturulmalıdır.

- Yerleşke içinde ücretsiz rekreasyonel bilgilendirme ve bilinçlendirme etkinlikleri düzenlenmelidir.

- $\quad$ Öğrenci kulüplerinin faaliyetleri daha etkin hale getirilmeli ve Üniversite yönetimi tarafından maddi yönden desteklenmelidir.

- $\quad$ SDU yerleşkesinde zaman içinde ortaya çıkabilecek rekreasyonel tecrübe ve değiş̧imler rekreasyonel faaliyetlere olan katılımları ve talepleri de etkileyebileceğinden Yerleşke içinde rekreasyon katılımcı profilinin ve değişimlerin devamlı olarak gözlenmesi ve buna göre gerekli tedbirlerin alınması gerekmektedir.

SDU yerleşkesinde rekreasyonel amaçı mekânsal ve tesis kapasitesinin artırılması ve etkinlik çeşitliliğinin geliştirilmesi hizmet veren hizmet alan herkes için aslında bir aidiyet duygusu oluşturmasına yol açacaktır. Yerleşkedeki rekreasyonel potansiyel SDU kimliğinin geliştirilmesinde de önemli rol üstlenecektir. Çünkü yaşam mekânı özellikleri ile rekreasyonel etkinliklerin özellikle mekânsal aidiyet duygusu üzerinde önemli bir ilişkisi olduğu belirlenmiştir (Eisenhauer et al.,2000; Pretty et al.,2003)

Sonuç olarak; SDU Yerleşkesinde yaşanabilir, sürdürülebilir, estetik, işlevsel, huzur ve mutluluğu optimize eden bir yerleşke mekânı konseptinin oluşturulması hedeflenmelidir.

\section{Kaynaklar}

Arkun, A.K. ve Özkal, Ç. (2005). Bilkent Üniversitesi Kampusu Peyzaj Analizi. Yüksek Lisans Dersi Sunum Ödevi. Ankara.

Balcı, V. ve İlhan, A. (2006). Türkiye'deki Üniversite Öğrencilerinin Rekreatif Etkinliklere Katılım Düzeylerinin Belirlenmesi. Spormetre Beden Eğitimi ve Spor Bilimleri Dergisi, 4(1), 11-18.

Bucher, C.A. and Bucher, R.D. (1974). Recreation For Today's Society. Prentice-Hall, Inc., Englewood Cliffs, New Jersey.

Cardinal, B.J., Jacques, K.M. and Levy, S. S. (2002). Evaluation of a university course aimed at promoting exercise behavior. Journal of Sports Medicine and Physical Fitness, Vol. 42, Issue.1, p.113. 
Dawer P.W. and Pangraz, R.P. (1975). Dynamic Physical Education For Elementary School Children. 4 th Edition, Washington, USA.

Demir, C. ve Demir, N. (2007). Bireylerin Boş Zaman Faaliyetlerine Katılmalarını Etkileyen Faktörler İle Cinsiyet Arasındaki İlişki: Lisans Öğrencilerine Yönelik Bir Uygulama. Ege Akademik Bakış Dergisi, 6(1), 36-48.

Eisenhauer, B.W., Krannich, R.S. and Blahna, D.J. (2000). Attachments to Special Places on Public Lands : An Analysis of Activities, Reason for Attachments, and Community Connections. Society \& Natural Resources, $13: 421-441$.

Göktaş, Z. ve Çolak, M. (2006). Vergi Dairesi Başkanlığında Çalışan Personelin Boş Zamanlarını Değerlendirmesi Üzerine Bir Araştırma (Balıkesir Örneği). 9. Uluslararası Spor Bilimleri Kongresi.

Günaydın, M., Demirel, Ö. ve Düzgüneş, E. (2012). Rekreasyonel Eğilimlerin Belirlenmesinde Üniversite Yerleşkelerinin Rolü: K.T.Ü. Kanuni Yerleşkesi (Trabzon) Örneği. I. Rekreasyon Araştırmaları Kongresi, 12-15 Nisan, S:364-380, Antalya.

Huang, C.Y. and Carleton, B. (2003). The relationships among leisure participation, leisure satisfaction, and life satisfaction of collegestudents in Taiwan, Journal of Exercise Science and Fitness, 1(2), p.129-132.

Iwasaki, Y. and Mannell, R. (2000). Hierarchical dimensions of leisure stress coping. Leisure Sciences, 22(3), 163-181.

Iwasaki, Y. and Schneider, I. E. (2003). Leisure, stress and coping: an evolving area of inquiry. Leisure Sciences, 25, 107-113.

İskender, A., Avcı, C. ve Yaylı, A. (2015). Gençlerin serbest zaman değerlendirme aracı olarak rekreatif faaliyetlere katılım düzeylerinin belirlenmesi Journal of Recreation and Tourism Research. JRT2 (1), SSN:2348-5321 36-42 .

Karaküçük, S. (2008). Rekreasyon- Boş Zamanları Değerlendirme. Gazi Kitabevi. Ankara.

Kır, İ. (2007). Yüksek Öğretim Gençliğinin Boş Zaman Etkinlikleri: Ksü Örneği. Kahra Fırat Üniversitesi Sosyal Bilimler Dergisi, 17(2), 307-328.

Kiper, T. (2009). Namık Kemal Üniversitesi Ziraat Fakültesi Öğrencilerinin Rekreasyonel Eğilim Ve Taleplerinin Belirlenmesi. Tekirdağ Ziraat Fakültesi Dergisi 6(2):191-201.

Mansuroğlu, S. (2002). Akdeniz Üniversitesi Öğrencilerinin Serbest Zaman Özellikleri ve Dış Mekân Rekreasyon Eğilimlerinin Belirlenmesi. Akdeniz Üniversitesi Ziraat Fakültesi Dergisi, 1582, s;5362.

Mete, B. ve Ağaoğlu, S.A. (2003). Ondokuz Mayıs Üniversitesi Kurupelil Kampüsü Akademik ve İdari Personelin Rekreatif Aktivitelere Katılım ve Bakış Açılarının incelenmesi", Beden Eğilimi ve Sporda Sosyal Alanlar Kongresi Bildiriler Kitabı, 5.42]-426, Ankara.

Müderrisoğlu, H. ve Uzun, S. (2004). Abant İzzet Baysal Üniversitesi Orman Fakültesi Öğrencilerinin Rekreasyonel Eğilimleri. Süleyman Demirel Üniversitesi Orman Fakültesi Dergisi. A(2):108-121.

Önder, S. (2003). Selçuk Üniversitesi Öğrencilerinin Eğilim Ve Taleplerinin Belirlenmesi Üzerine Bir Araştırma. Selçuk Üniversitesi Ziraat Fakültesi Dergisi 17 (32):31-38.

Özbaydar, S. (1983). İnsan Davranışlarının Sınırları ve Spor Psikolojisi. Altın Kitaplar Yayınevi, İstanbul, $50 \mathrm{~s}$.

Pehlivanoğlu, T. (1987). Belgrad Ormanı'nın Rekreasyon Potansiyeli ve Planlama Illkelerinin Tesbiti. Doktora Tezi, i..Ü. Fen Bilimleri Enstitüsü, İstanbul.

Pretty, G., Chipuer, H. and Bramston, B. (2003). Sense of place amongst adolescents and adults in two rural Australian towns: The discriminating features of place attachment, sense of 
community and place dependence in relation to place identity. Journal of Environmental Psychology, 23; 273-287.

Pulur, A. (2003). Üniversitede Görev Yapan Öğretim Elemanları ve İdari Personellerin Boş Zamanlarının Sporla Değerlendirme Eğilimlerinin Araştırılması (Kırıkkale Örneği)". Beden Eğitimi ve Sporda Sosyal Alanlar Kongresi Bildiriler Kitabı, s.427-432, Ankara.

Rowland, M. (1996). Principles for Campus Landscape Planning. The Regents of the University of California, USA.

Sabbağ, Ç. ve Aksoy, E. (2011). Üniversite Öğrencileri Ve Çalışanların Boş Zaman Etkinlikleri: Adıyaman Örneği Mehmet Akif Ersoy Üniversitesi Sosyal Bilimler Enstitüsü Dergisi Yıl: 3 Sayı: 4 2011-Bahar s. 10-23.

Süzer, M. (1997). Üniversite Öğrencilerinin Sosyal ve Ekonomik Özelliklerine Göre Boş Zaman Faaliyetlerini Değerlendirme Biçimleri (Pamukkale Üniversitesi Örneği). Yayınlanmamış Yüksek Lisans Tezi. Hacettepe Üniversitesi, Sosyal Bilimler Enstitüsü.

Tekin, M., Yıldız, M., Akyüz, M. ve Uğur, O.A. (2007). Karaman Yüksek Öğrenim Kredi ve Yurtlar Kurumunda Kalan Üniversite Öğrencilerinin Rekreatif Etkinliklere Katılım ve Beklentilerinin Incelenmesi. Erzincan Eğitim Fakültesi Dergisi, 9(1): 121-135.

Tel, M. ve Köksalan, B. (2008). Öğretim Üyelerinin Spor Etkinliklerinin Sosyolojik Olarak İncelenmesi (Doğu Anadolu Örneği). Fırat Üniversitesi Sosyal Bilimler Dergisi, 18(1), 261-278.

Tunçkol, H.M. ve Çumralıgil, B. (2005). Selçuk Üniversitesindeki Akademik Personelin Rekreasyon Faaliyetlerinin Değerlendirilmesi. Beden Eğitimi ve Spor Bilimleri Dergisi, 7(4), 45-51.

Uzun, G, ve Altunkasa, M. F. (1991). Rekreasyonel Planlamada Arz ve Talep. Ç.Ü. Ziraat Fakültesi Genel Yayın No: 6, Yardımcı Ders Kitapları Yayın No: 1, Adana.

Yerlisu Lapa, T. ve Ardahan, F. (2009). Akdeniz Üniversitesi Öğrencilerinin Serbest Zaman Etkinliklerine Katılım Nedenleri ve Değerlendirme Biçimleri. Spor Bilimleri Dergisi. (Hacettepe J. of Sport Sciences) 2009, 20 (4), 132-144.

Yetiş, Ü. (2008). Kamu Kuruluşlarında çalışan Devlet Memurlarının Boş zaman Faaliyetlerini Değerlendirme Alışkanlıkları (Tugsaş Örnegi). Beden Eğitimi ve Spor Bilimleri Dergisi, 10(2), 3445.

Wells, M. and Merriman, T. (2002). The outdoors and the classroom. Parks and Recreation, Vol. 37, Issue.3, p. 94-100. 